\title{
Messages on memorial Internet websites relating to suicide in Norway and Sweden ${ }^{1}$
}

\author{
Anders Gustavsson, University of Oslo, Norway
}

Earlier I have presented a study of messages published on memorial Internet websites relating to death in general (Gustavsson 2011, p. $142 \mathrm{ff}$.). In this paper I will present my study of memorial websites relating to persons who have committed suicide. I have found these websites set up at the same websites as those that commemorate other dead persons, for example www.tillminneav.se which means 'to the memory of'. Speaking openly about suicide is both remarkable and unique when contrasted with the reticence of former days. Messages expressed in these exceptional situations have not previously been subjected to scientific analysis. The aim of the present study is to determine which elements are common to memorial websites for both suicides and other categories of deceased persons, and which are distinctive. In addition, a comparison will be made between conditions in Sweden and in Norway. It should be noted here that there are about 1500 suicides in Sweden each year ${ }^{2}$ and about 500 in Norway. ${ }^{3}$

My research deals with memorial websites that have become available during 2009 and 2010 in Norway and Sweden. The all-inclusive issue in the present study concerns how mourners express their emotions, experiences and concepts of belief regarding the deceased person. This can be done verbally, by publishing written descriptions and poems, or illustratively, by using pictures such as photographs or pictorial symbols. Do concepts of a life after death exist and how are these expressed? What is the deceased's status considered to be on the other side and is she or he accessible in any way for the mourners? Can the dead be aware of and perceive the messages that the living send to them? Is any form of dialogue possible with them? Can the living at some future time after their own deaths be reunited with their dead loved ones and friends? These questions are identical to those I raised in my study of memorial websites for deceased persons who had not committed suicide (Gustavsson 2011, p. 142 ff).

This paper can play a part in the discussion about greater outspokenness concerning death, compared to the prevalent silence and tabooing of the twentieth century. How candid do close relatives and friends of the deceased dare to be in

\footnotetext{
${ }^{1}$ This paper was originally presented at the SIEF conference, Lisbon, April 2011, and complements my Cultural studies on death and dying in Scandinavia published in 2011.

${ }^{2}$ www.ne.se/självmord (all websites were accessed 1 March 2012 unless mentioned otherwise)

${ }^{3}$ www.levenorge.no
} 
speaking of suicide on the Internet? How must one respond, not only to societal norms, but also to the fact that these can change with the passage of time?

Reticence concerning suicide has a historic basis in that an action of this kind once constituted a crime against the state. Suicides were not allowed to be buried in the sanctified terrain of a churchyard, but were instead buried in a secret location somewhere in a forest. This is clearly stated in the section on criminal deeds in the Swedish law of 1734. The criminalization of suicide ceased with the new Swedish Criminal Code adopted in 1864. Changes in the Ecclesiastical Law at the same time allowed suicides to be buried in churchyards, although only in secluded corners and in private, i.e. with no ringing of the church bells. The coffin was not borne in through the churchyard gate but lifted over the churchyard wall, as has been told in numerous folk-life records. In some districts there were special stairs cut into the churchyard wall for this specific purpose. A new law on funerals passed in 1908 eliminated the provision requiring private funerals for suicides. They were now allowed the same form of funeral as other deceased persons (Pleijel 1983, p. 57 ff.; Odén et al 1998, p. 11 ff.). A negative opinion of suicides and their burial persisted, however, far longer in folk tradition. The despised northernmost corner of the churchyard was called "self-waster's cranny" or "suicide's corner". As the ethnologist Louise Hagberg, who wrote about death in folk tradition, states in a book published in 1937: "The horror of suicides is still deeply rooted, however. Even now there are those who find it extremely improper that suicides are allowed burial in the churchyard alongside respectable people. Suicides are generally considered in many places to have misused their right to be buried in sanctified earth (Hagberg 1937, p. 504).

In Norway, Christian V's Norwegian Law of 1687 stated that suicides were not to be buried in a churchyard. This regulation was abolished in 1842 (Nybø 2007, p. 17), or 22 years earlier than in Sweden. A prohibition on the graveside ceremony of sprinkling earth on the coffin was retained until 1897. After this date only the aiding and abetting of suicide is considered a punishable act.

\section{Specialities of memorial websites relating to suicidal acts}

\section{Criticism directed towards the deceased in Sweden and Norway}

One feature that is clearly specific to memorial websites relating to suicide is the criticism expressed in many cases towards the deceased. In Sweden this criticism is based on the deceased's not having considered the suffering she or he has brought upon the closest relatives, who are left feeling completely helpless. A young man named Janne took his own life when he and his girlfriend were 19 years of age. They had met in the evening, and had hugged and kissed each other. That same night he gassed himself to death, despite having said to his girlfriend, "see you tomorrow". She expresses her anger in the following way: "Oh, how mad I was at him. How could he do this to me? We who had planned to sit there together at the 
old peoples' home, drinking beer and smoking Marlboros". ${ }^{4}$ Other messages speak of the act of betrayal committed by the deceased towards those closest to him. Close relatives even express their anger over what has happened in newspaper articles. The newspaper Aftonbladet had an article in 2010 in which the ex-partner of the actor Micke Dubois, who had committed suicide in 2005, declared: "I have been so bloody mad at him for leaving me and our three children. Sometimes I've just wanted to dig Micke up so I could hit him. But those feelings come less and less often" (Aftonbladet, 5 March 2010).

A different form of criticism expressed in Norway is more negative than in Swedish messages, namely that suicide is an expression of egoism or cowardice in those that commit this action. The author of a poem entitled "Silje" writes:

I remember your death, still beautiful, but gone ...

I thought you were a coward

Who didn't dare continue on.

Did you find the peace you sought?

(Til Minne, Silje) $^{5}$

Erika wrote in a message on 19 September 2006: "Committing suicide is just so egoistic! Giving all that pain to those one supposedly loves is unthinkable to me. [...] What I see now is that if it hadn't been for my mum's egoism I could maybe still have had a mother. And that's what I don't have. Maybe it's sad that she didn't find enough joy in caring for me. But to let me grow up motherless is just so egoistic!"

Some of the other Norwegian messages written by close relatives have, however, questioned so negative an attitude towards those who have taken their lives. This is clearly expressed in Krokoline's $b \log ^{7}$ in which she opposes the view that suicide is an egoistic action. Thea wrote a message on 17 September 2006 in support of Karoline's opinion: "Oh! HURRAH for what you wrote! I do so agree with you! A person who was really close to me took her own life and then it's really provoking when people call suicide egoistic. The person I knew who took her life was really down and couldn't see any light at the end of the tunnel. I do so understand her. Great that there's finally a blog here that spreads some sense. HURRAH! Once more!" Krokoline closed this blog on 7 April 2007. This may indicate that she considered the answering messages to have given her success in what she was striving for, namely an attempt to alter prevailing attitudes.

\footnotetext{
${ }^{4}$ www.metrobloggen.se/jsp/public/permalink.jsp?article=19.6367435 (accessed 1 April 2011)

${ }^{5}$ www.levenorge.no

${ }^{6}$ www.krokoline.vgb.no (19 September 2006)

${ }^{7}$ www.krokoline.vgb.no
} 


\section{Self-reproach in Swedish messages}

On Swedish memorial websites, near relatives frequently express the fact that the suicide was totally unexpected and that they had had no prior indications. This applies especially to suicides who had not shown signs of mental disturbance or had been undergoing any form of psychiatric treatment. The totally unexpected suicide leads to anxiety and self-reproach among the nearest relatives. Had they been unaware of something in their contacts with the deceased that could have hindered it? When a 17-year-old girl named Tammi took her life in 2009, her family expressed their despair in the following way: "Tammi did not leave a letter for us. [...] Why didn't we notice how sick she was? Why didn't we understand that she didn't want to live? What have we done wrong? What should we have done? How should we have met her? We just didn't see her inner demons. [...] We didn't realize how strong those inner demons were". ${ }^{8}$ Such candid statements occur fairly often in Sweden, but hardly ever in Norway, where reticence in expressing inner emotions concerning suicide appears to be greater.

Relatives have spoken not only of inner demons, but in some cases also about outer factors in the deceased's lifestyle when they try to find reasons for why the suicide occurred so unexpectedly. The mother of the nineteen-year-old Robert who took his life in 2006 expresses her thoughts in this way: "Was there too much partying and too many computer games at night, too little sleep and too heavy demands at school? [...] Robert was a very sensitive person but kept everything locked up inside him". "When Christian took his life, the reason appears to have been the debts he had contracted in overly enthusiastic poker playing. His mother expresses her despairing wonder in the following way on 3 March 2008, sixteen months after her son's death: "What crime have we committed to be sentenced for life in this way? A life-long sentence with an obligation to survive!". ${ }^{10}$

In other cases relatives refuse to speculate and reason about the grounds for the death, but are left, on the other hand, completely shocked and unable to comprehend their own suffering. They also express a desire to pardon what has happened and that they love, grieve for and remember the deceased. Love, grief and remembrance are key words on memorial websites for all deceased in general, as they are here in relating to suicide.

In instances of other types of sudden death, due to accident, murder or manslaughter the nearest relatives are not burdened with the same self-reproach for not having done enough to hinder the incident. The death has been caused by external events (traffic accidents, boat accidents, or murderers), and not by the deceased's mental condition and anguish for which assistance and proper care might have been arranged.

\footnotetext{
${ }^{8}$ www.tillminneav.se/showPage.php?id=857

${ }^{9}$ www.freewebs.com/robbansminne

${ }^{10}$ www.christiansellergren.se
} 


\section{Criticism of psychiatric treatment in Sweden and Norway}

In other cases suicide has not been as unexpected as in the above examples. This is when the deceased has been under psychiatric treatment for lengthier or shorter periods of time. Criticism by the relatives is then directed, not towards the deceased, but towards this treatment, which is seen as having been inadequate. The shortcomings are considered to have been largely responsible for the suicide. This can refer to, for example, unsatisfactory supervision of the patient that has allowed her or him to commit suicide in an unguarded moment. Ehline took her own life in 2007 at 31 years of age. On 29 January 2009 her mother wrote on her memorial blog: "Ehline's $33^{\text {rd }}$ birthday would have been tomorrow, but psychiatry took that from us. [...] Those people in psych.care should know how Ehline's family feel, they just don't understand what they've done to us. I often write about how angry I am with psychiatry and I know I have a right to that. [...] The way they prescribe pills for patients and then tell me about their bad side effects. You get scared just listening. And there's a lot of profit-making in it. [...] I'm never going to get over everything that's happened and I'm going to fight to get a change in psychiatric care. Patients need more than pills, they need to talk to someone [...] but psych.care can't be bothered to help them". On 20 April 2009 this mother wrote: "38 different kinds of pills in 7 months - anyone can see that this won't help a sick person". ${ }^{11}$ Newspapers also revealed shortcomings in psychiatric care in interviews with relatives, especially those of well-known artists such as the actors Micke Dubois (who died in 2005) and Johanna Sällström (who died in 2006). As Sällström's father informed the newspaper Ystads Allehanda in 2007: "There was no treatment in the real sense of the word. She was kept doped with psycho-drugs. And she was massaged a little by a physiotherapist. But it was mostly a matter of keeping her quiet at the hospital" (Ystads Allehanda, 4 May 2007).

This form of clearly expressed criticism of psychiatric care by the deceased's relatives is also found in Norway. Just as in Sweden, it is also taken up in newspaper interviews with close relatives. The press then agrees with the criticism of society's system of care as revealed by these relatives. On 2 December 2004 the newspaper $V G$ devoted an entire page to a case of this kind. "Berit (aged 49) hung herself in the hospital smoking room. That was the only place Norwegian psychiatry could find to put her. Her daughter is shocked. [...] This daughter fought the psychiatric health service desperately for three years trying to keep her mother alive. She lost that battle. [...] Now I'm going to fight on so that no-one else will feel as helpless and alone as I did, says the daughter to $V G$ " $(V G, 2$ December 2004). On 15 February 2005 the newspaper Dagbladet took up another case of suicide at a psychiatric ward in Oslo. Here one critical comment was that "psychiatry is still regarded with silence. This makes it even more important for the press to throw light on a system that endangers human life" (Dagbladet, 15 February 2005).

${ }^{11}$ www.minneavehline.blogg.se 


\section{Swedish repudiation of suicide guides}

A subject dealt with in numerous Swedish messages, and also in the media, is a strong rejection of the suicide guides found on the Internet. In such guides, potential suicides can learn about various methods for taking their own lives. Some of those who did commit suicide obviously visited these websites. Christian's mother wrote a long article on his memorial website entitled "The worst day of my life". In it she describes how she and her husband found Christian dead of carbon monoxide poisoning in the bathroom of his apartment. He had deliberately inhaled the poisonous fumes. The parents searched his laptop. His mother writes: "We spent that whole weekend checking his laptop for clues. Using different links, we could trace what he had been reading on his laptop in those last hours. We clicked on the links and arrived at different sites with precise descriptions of how to succeed in committing suicide. It just makes you sick to know that there actually are people who publish such sites. Christian found sites describing how to light a charcoal grill in a closed room, and that's exactly what he did. So that nobody else would get hurt, he tacked a warning note on the door (we didn't see it, the ambulance personnel took it down), 'Danger. Carbon monoxide. Poisonous!'”. ${ }^{12}$ In a guestbook message posted on Christian's memorial website on 19 September 2008, Bella wrote about her own experiences that could easily have resulted in suicide: "Was so sick a while back. Had taken an overdose and landed in the IVA $^{13}$, but I'm much better now. Have visited sites with suicide guides, but get so angry that those things exist! And that they're still there".

Relatives of suicides have worked even more actively in recent time to have these guides forbidden. A blogger, who advocates the ideal of "no suicides" after having lost his father due to suicide in 2005, wrote on 21 October 2010: "Close these suicide-promoting sites. A campaign has been started to get a legal prohibition on suicide sites. Click here to support us. [...] If mercy killing is illegal $^{14}$, encouraging others to take their own lives shouldn't be permitted either". ${ }^{15}$ Articles in Swedish newspapers have also focussed on suicide guides and supported a ban on them. The Göteborgs-Posten for 16 October 2010 carries the article "Suicide sites - support or risk?" commenting on the demands now being put forth for a Swedish ban on sites that promote suicide. Among those quoted is Gunilla Wahlén, the president of SPES ${ }^{16}$. She fully supports removal of the harmful suicide sites on the Net. This has been done in France and Portugal. Norway prohibits all aid to suicide. A prohibition of this kind is a precondition for achieving the goal of zero suicides among young people (Göteborgs-Posten, 16 October 2010). The media researcher Michael Westerlund, who published his

\footnotetext{
${ }^{12}$ www.christiansellergren.se

${ }^{13}$ Intensive care unit

${ }^{14}$ Euthanasia is illegal in Sweden.

${ }^{15}$ www.nollsuicid.blogg.se/2010/october/

${ }^{16}$ The Swedish association for the prevention of suicide and support of survivors
} 
doctoral thesis "Suicide and the Internet" in 2010, refers to case studies showing that individuals have taken their own lives or attempted suicide after finding information about suicide methods on the Internet. In 1995 Portugal prohibited all forms of propaganda supporting suicide or instructing about suicide techniques. A similar prohibition was adopted in France in 2002. Australia criminalized Internet sites promoting suicide starting in 2006. The principal website in Sweden, entitled www.sjalvmord.com, ${ }^{17}$ was started in 2005 (Westerlund 2010, p. 75 ff.). I have not found information about such sites in Norway, something that should be seen as a result of the prohibition on suicide assistance.

\section{Norwegian scepticism to memorial websites}

In Norway, in contrast to Sweden, scepticism towards memorial websites for suicides has been expressed fairly often, since it is thought that they could tempt others to commit suicide. An emotional contagion (sometimes known as "spillover effect") might occur, especially if those who have taken their own lives are honoured and glorified. It is also considered ethically indefensible to praise someone who has committed suicide and therefore caused immense psychological suffering to close relatives. A woman wrote on 5 May 2008 concerning a situation she experienced in her family: "When it comes to the subject of sites like these being able to trigger suicide: my in-laws have set up a site at gonetoosoon in memory of my brother-in-law who committed suicide last summer. I thought at first this was a good idea, and for some it is almost a kind of therapy to open the site and read everything posted there, and to write themselves about how much they miss him. [...] But I can also see the dangers in this, when the deceased is glorified and set up on a pedestal and almost presented like a hero. There's nothing there saying that he took his own life, or that he chose to leave his three children in that way. Many of us in the family still feel anger, why couldn't he have talked to someone about how he felt, instead of choosing the 'easy way out'? Such things are not often written about on these sites. You're somehow not supposed to talk about it. [...] I'm not in favour of making people better than they are, just because they're dead. I just wish my brother-in-law's kids could learn more about why their daddy is dead, instead of being taught that he's a hero who carried out a brave deed" ${ }^{18}$ I have not encountered similarly critical statements about memorial websites in Sweden. There is a greater moderation in Norway, almost unwillingness, to talk about committed suicides. This indicates that the former and very strong taboo on suicide, including a feeling of shame, is obviously more lasting in Norway. A Norwegian woman who lost her husband due to suicide in 2008 wrote a poem about what had happened. One verse reads:

\footnotetext{
${ }^{17}$ Accessed 1 April 2011. Meanwhile the website closed down "until further notice".

${ }^{18}$ www.forum.kvinneguiden.no/index.php?showtopic=332509 (accessed 1 April 2011)
} 


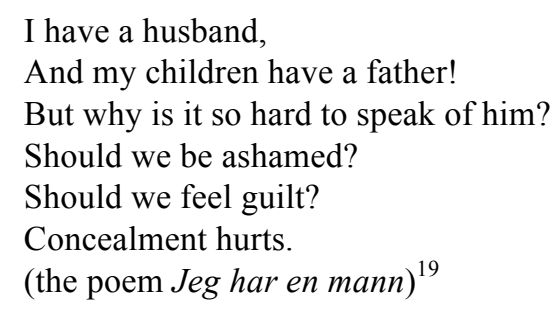

In Norway there is a "National association for the surviving relatives of suicides", abbreviated LEVE (meaning 'live' in Norwegian). Trude, who lost her sister because of suicide, praises LEVE as "a fantastic organization", but also adds: "How odd that it has so few members. Says something about this still being a tabooed subject". ${ }^{20}$ There are comparable support groups in Sweden that have played an important role for surviving relatives. These groups have been met with considerable sympathy and not with the same scepticism as in Norway. "The national association for the prevention of suicide and support of survivors", abbreviated SPES (in Swedish, the Latin word for 'hope'), founded as early as 1987, has about 1500 members. ${ }^{21}$ There is also a "West-Swedish network for suicide prevention", abbreviated WNS. Older traditions are not discarded in Norway as easily as in Sweden, however, as can also be shown in other connections having to do with death (see below).

\section{Moderation relating to suicide in Swedish and Norwegian media}

One might ask what the attitude of the media concerning the mention of suicide can have meant for people's interest in discussing such events on the Internet and in expressing themselves on the memorial websites there.

Paragraph 8 of the Swedish regulations for press ethics reads: "Show extreme caution in press coverage of suicide and attempted suicide, especially as regards the survivors and what is stated above concerning the sanctity of private life". 22

The question of whether to mention suicide became current with the death of the wrestler and European Champion Mikael Ljungberg on 17 November 2004. The journalist Jimmy Fredriksson wrote an article published two days later in the Göteborgs Tidningen entitled "We have to dare talk about it". He observes that "suicide is the most tabooed subject in Sweden. ${ }^{23}$ Actually, it doesn't even exist. We are brought up to say nothing about suicide, those of us in the press writing about it only in extremely rare circumstances. [...] If suicide is mentioned, everyone stops talking". Fredriksson then mentions Mikael Ljungberg's death, noting that "most people's first reaction was to quiet down what had happened. Suicide

\footnotetext{
${ }^{19}$ www.levenorge.no/tilminne (accessed 1 April 2011)

${ }^{20}$ www.levenorge.no/tilminne (accessed 1 April 2011)

${ }^{21}$ www.spes.nu; Westerlund 2010, p. 185.

22 http://www.po.se/regler/pressetiska-regler, cf. Westerlund 2010, p. 12.

${ }^{23}$ The bigger openness in Sweden came later.
} 
fosters thoughts of guilt and shame". This has to change, according to the author: "We have to realize that it's wrong to try to hide a societal problem that takes three times more lives than traffic accidents. Instead, we need an information campaign about suicide. We need a debate. We have to dare talk about people who take their own lives and to discuss why. Lives can be saved. [...] Parents must be helped to recognize the signals of suicide. [...] The taboo stamp must be removed. It may be that the debate and discussion that followed Mikael Ljungberg's death can help to do this" (Göteborgs Tidningen, 19 November 2004). On 15 December 2004 the managing editor of Expressen, Thomas Mattsson, continued in the same vein as Fredriksson. After Ljungberg's death, Mattsson promises, "we are going to write about suicide more often, about why it takes place and also report on the danger signals. This can help our readers and may even save lives. A self-imposed censor cannot, after all, benefit the treatment of the suicidal. [...] Our newspaper will wipe out the taboo saying that suicide should not be spoken of or written about, a relic of the age when it was a crime to take your own life" (Expressen, 15 November 2004). It is obvious that Ljungberg's death caused a change in the media. On 18 October 2005 the publisher of Journalisten, Qia Rindewall, wrote an article entitled "More suicides in the media". ${ }^{24}$ It can thus be said that Fredriksson's and Mattsson's expressly desired goal has been reached and their battle cries answered after 2004. It is in this period of time that more and more memorial websites are established for persons who have committed suicide. Here there appears to be a connection with the increased openness demanded and shown by the media in recent years.

Paragraph 4.9 of the current Norwegian Code of Ethics for the press ("Vær Varsom-plakaten") reads: "Be cautious when reporting on suicide and attempted suicide. Avoid reporting that is not necessary for meeting a general need for information. Avoid description of methods or other matters that may contribute to provoking further suicidal actions". ${ }^{25}$ This code of ethics applies as from 1 January 2006, while the previous code in effect from 1936 stated that "suicide or attempted suicide shall, as a general rule, not be reported on" in the press (Westerlund 2010, p. 12). The difference in comparison with the Swedish code of ethics is that the last sentence of the current code warns against the danger of provoking new suicidal actions.

The work of revising the Code of Ethics' paragraph 4.9 prior to 2006 was led by the journalist Reidun Kjelling Nybø. She was commissioned by the Norwegian Press Association to draw up a guide as to how suicides should be mentioned. The result of her work with these questions has been recounted for in the book "From taboo to topic. Suicide in the media" (Fra tabu til tema. Selvmord i mediene), published in 2007. The main title of the book indicates clearly that the author wishes to show that a change has taken place in the media's praxis. Nybø's guide is found on

\footnotetext{
${ }^{24}$ www.journalisten.se

${ }^{25} \mathrm{http}: / /$ presse.no/Etisk-regelverk
} 
pages 107 to 114 . As a general rule she states that "the changes in the Code's paragraph 4.9 do not mean that the media can now freely and uncritically report on every single suicide or attempted suicide. It is still the case that the great majority of suicides belong to a person's innermost being and private sphere. But in some instances it will be proper for the media to report on suicide as a general societal problem and, at times, also on individual suicides" (Nybø 2007, p. 108). There are two main reasons for showing consideration in any report of suicide and attempted suicide. One is the danger of influencing others, especially young people, to commit suicide. The other has to do with a consideration of the closest relatives and the deceased's posthumous reputation. "Despite increased openness, this is still a tabooed topic" (Nybø 2007, p. 109).

There was also a great deal of debate in the media in 2005 before the new Code of Ethics was adopted and began to be applied as of 1 January 2006. The newspaper Dagbladet ran a five-page report on 8 February 2005 about Katherine, aged 19 , who took her life in a psychiatric emergency room in Oslo. Most of the text was based on Kathrine's mother's revelations. She emphasized that "my only hope is that making this story public will stop this happening to others" (Dagbladet, 8 February 2005). The article was reported to the Norwegian Press Council ("Pressens faglige utvalg", abbreviated PFU) which on 25 April 2005 resolved that "Dagbladet had not violated ethical press conduct". The Council noted that the Code of Ethics was under revision and that "opinions about suicide and attempted suicide have changed in the past few years. The press has increasingly chosen to focus on the underlying causes of suicide as a societal and medical problem" ${ }^{26}$ The debate continued with the article "Should suicide be discussed?" written by the journalist Knut Olav Åmås and published in Aftenposten on 26 May 2005. He observed that "suicide is still partly tabooed by society, but changes in mentality have taken place that have also led the media to publish numerous background stories focussed on suicide, with details often provided after the event by the next-of-kin". The journalist favoured a continued restraint in the media concerning suicide, and ended by writing that "the media can at best contribute by making suicide a less tabooed topic in society and by focussing on viewpoints that can help individuals who find themselves in a difficult situation and also those close to them" (Aftenposten, 26 May 2005). The two college lecturers Hege Lamark and Jan-Erik Andreassen wrote an article in 2007 about the Norwegian media's references to suicide in the year 2006. They observed that "one year after the changes in the press's Code of Ethics, we find a great many articles about suicide in the media", but that "local newspapers almost never mention suicide at all". The authors are pleased, however, that seen as a whole, "the taboo associated with suicide has been weakened, and suicide can be made an open topic" (Suicidologi, 2007, no 2).

Krokoline, whose father had committed suicide by hanging, also evaluates this first year with the new Code of Ethics in her blog of December 2006. She is more

${ }^{26}$ www.pfu.no, 25 April 2005, cf. Nybø 2007, p. 68 ff. 
pessimistic than Lamark and Andreassen, stating that "it is difficult to get the press to report on the suicide problematic. It seems as if it's better to sweep suicide statistics under the carpet together with all the other awful dust bunnies". She hopes that the media will begin to write more about "preventing suicide or what it's like to survive someone who's committed suicide". Her experiences indicate something different, however: "The newspapers I contact about this just don't get a move on" ${ }^{27}$ The journalist Reidun Kjelling Nybø also observes in her book of 2007 that "there is still a great deal of taboo connected to suicide" in the Norwegian media (Nybø 2007, p. 10).

Generally speaking, one sees that it is just in the late 2000s that a few memorial websites for people who have committed suicide begin appearing, although to a far lesser extent than in Sweden. The somewhat greater openness in the media after the appearance of the new Code of Ethics may have been a source of inspiration. All in all, however, it has been more difficult in Norway than in Sweden to break with an earlier and established tradition concerning reticence in writing and speaking of suicide.

\section{Similarities to memorial websites about other deceased persons}

\section{A belief in an afterlife in Sweden}

Despite their sorrow, sense of loss and shock, some Swedish statements and guestbook messages show that close relatives find comfort in believing that the person who died by suicide can have come to a different existence after death. It is believed to be better than the life the deceased once had and consciously chose to leave. This new existence is, however, conceived of as being diffuse, in keeping with the conceptions expressed about other present-day deceased persons. These are not traditional religious conceptions. No thoughts of punishment after death are expressed. This corresponds fully with the neo-religious conceptions of "the regained paradise" written about by the folklorist Bente Gullveig Alver (Alver 1999b). A message about Maja, who committed suicide in 2009 when 26 years of age, notes: "She chose to go on to a new life, where she is probably happier than here on earth". ${ }^{28}$ Daniela's mother conceives of her daughter's afterlife as being more tangible and resembling what is best here on earth. She writes on 8 November 2007: "I hope that Christian and my Daniela have become pals in a warm country with sunny beaches". ${ }^{29}$

The surviving relatives are also believed to be able to make contact with the deceased in the latter's new existence. After Johan committed suicide in 2005 at the age of 44, a sister wrote: "I talk to you every day, hope you hear me, see me,

\footnotetext{
${ }^{27}$ www.krokoline.vgb.no

${ }^{28}$ www.evigaminnen.se, Maja Kovalski

${ }^{29}$ www.christiansellergren.se
} 
and are with me. Love you forever". ${ }^{30}$ In some cases, contact with the deceased is said to have taken place with the aid of a medium. A year after Robert, aged 19, had committed suicide, his mother wrote on 25 April 2007: "Robert's older sister visited a medium yesterday, the $24^{\text {th }}$, and she contacted Robert". He said that "he misses us very much and is with us down here and watches over us". His mother gained some comfort from this. At the same time, she became "terribly unhappy" on learning that he had said he hadn't meant to take his life. "He just wanted to scare us and it went too far". ${ }^{31}$ Mediums have also been consulted in cases of death other than suicides. Such conceptions about mediums and their prospects of making contact with a supernatural world are fundamental to the neo-religious movement called New Age (Gilhus and Mikaelsson 2005, p. 166 ff.).

Numerous messages also mention the probability of a reunion between the surviving relatives and the deceased in some vague future. This is the same conception that is often linked to other deceased persons. A sister of the Pierre who took his life in 2005 when 20 years of age, writes: "I hope you will meet all of us, one after the other, with wide-open arms when it's our turn to come to the other side, because I know you are there somewhere and are waiting for us". ${ }^{32}$

The deceased can also meet angels in the afterlife who care for him or her.

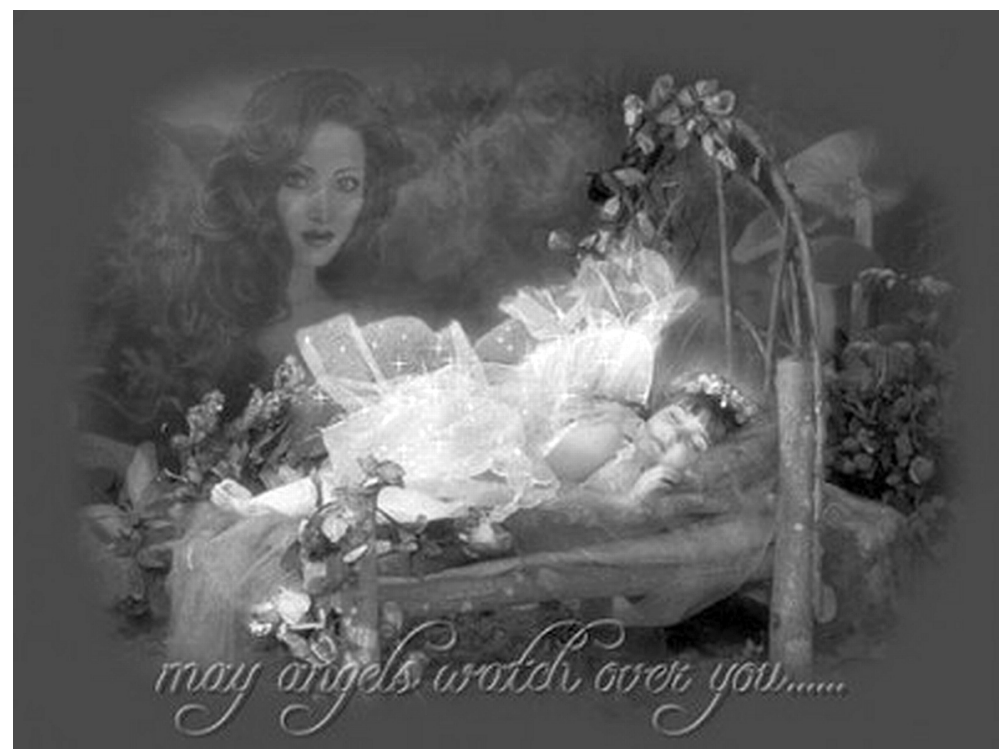

This picture was published on a memorial website for Ehline, who committed suicide in 2007 when 31 years old. The text reads: "May angels watch over you". ${ }^{33}$

\footnotetext{
${ }^{30}$ www.tillminneav.se, Johan Ryglert

${ }^{31}$ www.freewebs.com/robbansminne/

${ }^{32}$ www.tillminneav.se, Pierre Johansson

${ }^{33}$ www.minneavehline.blogg.se (15 May 2010)
} 
There are some cases in which the "City of angels" is mentioned. As Christian's mother wrote on Christmas Eve 2007: "Hope you have as happy a Christmas as possible up there in the city of angels, my dear boy!". ${ }^{34}$ When angels are mostly spoken of as supernatural or divine beings, this is on a line with the neo-religious New Age conceptions in which God is less present (Alver 1999a).

The deceased can also be conceived of as being an angel, as other deceased persons in Sweden often are. This conception of the deceased being an angel is more frequently spoken of than are conceptions of angels helping the deceased.

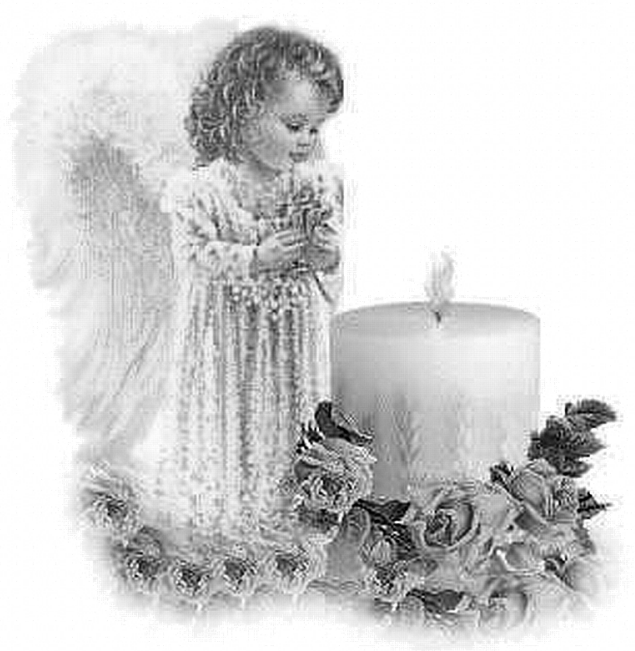

"Light a candle for my angel-child", wrote Ehline's mother on 31 October 2009. ${ }^{35}$

A glorification of the deceased often occurs in which the latter is seen as being the best angel that can be found. After Robin took his life in 2008 when 20 years old, his mother wrote to him: "Robin, now you're a real angel, the loveliest, most wonderful angel in the whole universe. Sleep well, my child, we'll meet again some day" ${ }^{36}$ Here one might ask if a glorification of this kind could tempt others into committing suicide, as is a widespread belief in Norway. The conception of the deceased's getting the form of an angel and even of being the best, finest and loveliest angel also concurs with conceptions on Swedish memorial websites for other deceased persons (Gustavsson 2011, p. 151 ff.). Upon becoming an angel, the deceased is thought to be able to watch over and protect the surviving relatives on earth. The mother of the above-mentioned Ehline, who had committed suicide in

\footnotetext{
${ }^{34}$ www.christiansellergren.se

${ }^{35}$ www.minneavehline.blogg.se (10 September 2010)

${ }^{36}$ www.tillminneav.se, Robin Erik Lindahl Uhlig
} 
2007, wrote on 23 May 2009: "I hope she is with us in heaven and protects her brothers and me and those little ones ${ }^{37}$ who will soon be here". ${ }^{38}$

In Norway one does not encounter conceptions of an existence after death for those who have committed suicide. Angels are, therefore, not mentioned either. There is not only more reticence in Norway about speaking of suicide, whether in the media or between private persons. There also appears to be more keeping to former negative beliefs about those who commit suicide with reference to a coming afterlife. Keeping to a conception of this kind makes it impossible to conceive of a bright, heavenly existence together with angels, or that the deceased could himself/ herself become an angel. In this respect, the contrast with Sweden is very obvious. The stability of tradition is clearly more evident in Norway.

\section{The significance of writing on memorial websites in Sweden}

The people writing messages on memorial websites for suicides are, above all, women. They are the mothers, wives, partners, girlfriends or sisters of the deceased. This is in complete accordance with what is found on memorial websites for other deceased persons (Gustavsson 2011). Numerous Swedish messages refer to the value of being able to talk and write about suicides that have occurred in the personal circle. But this increased openness in expressing oneself has been late in arriving, as numerous writers have confirmed. Alexandra was eight years old when her father took his life at age 33. She first became aware of this when she was 19 years old, which was something she subsequently regretted deeply. What is needed, in her opinion, is a far greater openness than was the case previously. She writes: "The advice I'll give you, based on my own experience and regardless of gender or age, is to TALK! ... Write about it! ... Even if you only meet silence or rejection from your surroundings, don't give up, there will always be someone who will help you feel less alone. [...] In our day we have the Internet, organizations and support groups in different parts of the country. Go to them and talk to people who can sympathize with your thoughts and feelings". ${ }^{39}$

Memorial websites can sometimes be developed to honour or even glorify the deceased, and not only to express distress or shock over what has taken place. When the nineteen-year-old Charlie committed suicide in 2008, his older sister wrote: "This page is a way to honour Charlie, a great guy" ${ }^{40}$ Christian's mother, who had set up a memorial website about him, wrote on 30 September 2009: "I want you to know, Christian, that I'm so enormously proud of you and so grateful for being the one who had the honour of being your mum". ${ }^{41}$

\footnotetext{
${ }^{37}$ Grandchildren

${ }^{38}$ www.minneavehline.blogg.se, (23 May 2009)

${ }^{39}$ www.ungaisorg.se, Alexandra Lundsten (29 April 2009)

${ }^{40}$ www.tillminneav.se, Charlie Nilsson

${ }^{41}$ www.christiansellergren.se
} 
The surviving relatives often comment on the psychological help they have received by reading the comments and messages published in the guestbooks. Linnea's mother, who set up a blog after her 14-year-old daughter had thrown herself in front of a train, wrote the following about her experiences: "It means a great deal to me to know that there are so many of you out there who think about me, think about Linnea and understand our problems. Your comments mean so much to me. Both because then I know I'm not alone, and because I am often forced to point my thoughts in a new, different direction when I read the reactions to my messages". ${ }^{42}$ Christian's mother noted on 23 November 2007 that "by today your homepage has had over 14000 visitors. [...] It is comforting to see that so many think of you and of us". On 30 September 2009, the mother noted that: "today the count registered over 50000 visitors on your website, Christian! Unbelievable! I know that your fate has touched many people, but I would never have believed that the site would be visited by so many when I set it up". ${ }^{43}$ The comments posted on the memorial websites become a counterweight to and a help in coping with the sense of loss and grief, as Ehline's mother has wished to illustrate with a picture.

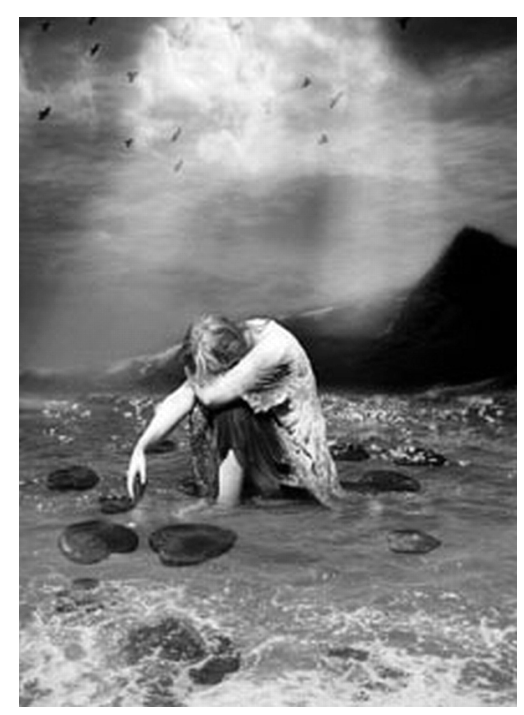

Ehline's (1976-2007) mother wrote about her grief and sense of loss on 4 September 2009: "Miss her so that my heart aches, it's so empty without her, feel like this picture, tears run and you feel really down. You miss your old self when you were happy and didn't have this pain inside you". 44

\footnotetext{
${ }^{42}$ www.ludmilla.se

${ }^{43}$ www.christiansellergren.se

${ }^{44}$ www.minneavehline.blogg.se (4 September 2010)
} 
Memorial funds have even been created recently for those who have committed suicide, similar to the funds set up in memory of other deceased persons. The newspaper Eskilstuna LNY reported about a fund of this kind on 20 August 2008, and about a grant from it: "On Wednesday evening a ceremony was held for the first grants awarded from Zandra Perrault's Memorial Fund. Zandra Perrault, a girl from Eskilstuna, took her life nearly two years ago and her parents have now set up a fund in her memory" ${ }^{45}$ This might easily be interpreted by outsiders as an idolization of the deceased, among whom the fact that she committed suicide would be seen as a negative action. The first instance of a memorial fund of this kind occurred after the death of the wrestler Mikael Ljungberg on 17 November 2004. In the sports section of Dagens Nyheter for 9 December 2004, mention is made that "Stig Strand has started a fund in Ljungberg's memory".

There are, in addition, a number of visitors on Swedish guestbooks relating to suicide who write that what they read about suicides on the memorial websites encouraged them not to take their own lives. They gained a clear understanding of how much suffering the suicide caused to the closest relatives and friends. The memorial websites have contributed, in other words, to the saving of lives, something that obviously contradicts the fear that they would tempt others to take their lives in what is called emotional contagion. Maria wrote on 23 October 2008: "I tried to take my own life in 2003 and 2004, but luckily I'm still here today. Understand how stupid it all was and that it was not the only answer. I wish you all the best". ${ }^{46}$ Andreas noted on 12 May 2009: "I'm glad you've not kept quiet about Christian's death. Information should be spread and no matter how hard it is to be one of those doing the spreading, it does most certainly help a lot of people. Among others, it helped me, and still does help at the times when I most of all would like to leave life behind. I know that I can't do it because I love my family too much to cause them that sorrow (and it would be sorrow even if I'm not exactly a saint). But it's useful to be reminded of the pain, and understand that it's worth the struggle - not always for my own sake but really for those I love. Thanks, and keep up the good work!". ${ }^{47}$

\section{Tradition and change in a Norwegian-Swedish perspective}

In general, this study has reached the conclusion that Norway is more restrained when it comes to expressing oneself about suicide. Former traditions have much more influence there than in Sweden, where changes have become more extensive during the twenty first century. In Sweden, the differences between suicides and other deaths have been increasingly wiped out. A standardisation has taken place comparable to what has occurred in many other areas of social life. Equality, not

\footnotetext{
${ }^{45}$ www.eskilstuna.lny.se/nytt-sjalvmord-i-eskilstuna-4597/ (accessed 1 April 2011)

${ }^{46}$ www.christiansellergren.se

${ }^{47}$ www.christiansellergren.se
} 
differentiation, is to concern all, according to the dominant political and medial norms that have become increasingly strong. In order to achieve equality, former boundaries separating people must be broken down. As ideas of equal worth for all people have become the great ideal, this is also expressed on the memorial websites for the deceased. The belief in some diffuse existence after death, conceptions of angels and a conviction about the surviving relatives' reunion with the person they have lost through suicide in some distant future is consistent with what is expressed on the memorial websites set up for deceased persons in general. This same consistency is valid to questions of glorification and honouring of the deceased.

In Norway the boundary between suicide and other deaths is marked in an entirely different manner. Glorification or expressions of honour are unthinkable, since this could lead to others being tempted to new suicides. A so-called emotional contagion is to be hindered in every possible way. In Sweden, however, there is a clearly expressed conception about how messages on memorial websites can prevent suicide in that they show the unfortunate effects this has on the closest relatives.

In Norway there are no concepts of a bright afterlife or of angels in connection with committed suicides. The Norwegian material consisting of memorial websites about suicide is quantitatively meagre compared to all that exists in Sweden. This indicates that the former tabooing of suicide containing elements of shame obviously is greater in Norway. Reticence concerning speaking of and writing about suicide is also noticeable in the media's presentations, even though a certain moderation has occurred after the new and more liberal Code of Ethics for the Norwegian Press was adopted in 2006. In Sweden, too, the media long showed reticence about mentioning personal names and writing articles about suicide. The death of the wrestler Mikael Ljungberg in 2004 came to result in a clearly observable change.

Even if equality and standardization have become the ideal in Sweden, there are also certain differences between the websites set up for those who have committed suicide and those who have died in other ways. This is shown by the criticism, and not only glorification, that can be expressed about those who have taken their lives. The deceased has caused extreme sorrow among the nearest relatives and friends. Criticism of this kind is even stronger in Norway than in Sweden. The words "egoism" and "cowardice" linked to the deceased are expressions that I have observed on Internet websites only in Norway.

One area in which criticism is similar between Norway and Sweden has to do with the shortcomings in psychiatric care. The similarity in this connection can be due to the fact that it is not the deceased, but instead society that has not accepted its responsibility and done more to prevent suicide. Extreme criticism is aimed in Sweden against the suicide guides that have recently begun to appear on the Internet, and that clearly further suicide through their descriptions of methods for 
taking one's own life. This criticism does not exist in Norway, because all forms of assistance to suicide are strictly forbidden by law.

An especially emotionally charged topic in Norway concerns suicide, attempted suicide and thoughts of suicide linked to homosexuality. The ethnologist Tone Hellesund studied this problem in the years 2002 to 2004 by interviewing twelve homosexual persons, half of them women and half of them men, who have attempted suicide or had thoughts of suicide (Hellesund 2008). My Norwegian Internet material contains no memorial websites for openly homosexual persons who have committed suicide.

Older traditions have been shown to survive longer in present-day Norway than in Sweden, even in other respects than memorial websites. In the latter country there is a greater tendency to adopt innovations and to leave the long-standing. This relates to the symbols on gravestones, the lack of pet cemeteries in Norway, and the far fewer memorial websites to dead pets. In addition, the messages posted on these websites are both shorter and less emotional than their counterparts in Sweden. Memorial websites to the deceased generally contain far more traditional Christian conceptions in Norway than in Sweden. This concerns, for example, references to God and Jesus. In Sweden one observes more of a diffuse, general religiosity that can remind one of New Age modes of thought in which individuals and the brightness of a coming existence have a prominent position.

It can be difficult to give an explicit answer as to why former traditions associated with the deceased in general and to suicides in particular have a stronger position in Norway. A more obvious degree of secularization clearly plays a role in Sweden. Another factor is the individualism that in many ways has been shown to be more evident in Sweden than in Norway. This is especially noticeable in the choice of symbols on gravestones in recent times. In Sweden there is often a tendency to regard what is new as being positive, to focus on the cheerful events emphasized by the media. The result can be that one covers over anything that is sorrowful. Life's darkest moments can be given a brighter shape. In this respect, Norway can be seen as being more realistic in its preservation of older traditions and in not merely leaving life's darker sides without further discussion.

\section{References}

Aftenposten (26 May 2005): Skal selvmord omtales? (by Knut Olav Åmås). Aftonbladet (5 March 2010): Avskedet (by Anders Johansson, Claes Petersson).

Alver, Bente Gullveig (1999a): Fra englevagt til englevinger. In: Bente Gullveig Alver et al. (eds.): Myte, magi og mirakel i möte med det moderne. Oslo: Pax Forlag.

Alver, Bente Gullveig (1999b): Paradise recaptured: experience, interpretation and narrative. In: Anders Gustavsson, Maria Santa Montez, eds.: Folk Religion: Continuity and Change, pp. 325-334. Lisbon: Instituto de Sociologia e Etnologia das Religioes [etc.].

Dagbladet (8 February, 15 February 2005): Selvmord i pressen. 
Dagens Nyheter Sport (4 December 2004): Stig Strand startar fond till Ljungbergs minne. Expressen (15 December 2004): Thomas Mattsson.

Gilhus, Ingvild; Lisbeth Mikaelsson (2005): Kulturens refortrylling. Nyreligiøsitet $i$ moderne samfunn. Second edition. Oslo.

Gustavsson, Anders (2011): Cultural studies on death and dying in Scandinavia. Oslo: Novus forlag.

Göteborgs-Posten (16 October 2010): Självmordssajter (by Dag Fransson).

Göteborgs Tidningen (19 November 2004): Vi måste våga prata om det (by Jimmy Fredriksson).

Hagberg, Louise (1937): När döden gästar. Svenska folkseder och svensk folktro i samband med död och begravning. Stockholm: Wahlström \& Widstrand.

Hellesund, Tone (2008): Identitet på liv og død. Marginalitet, homoseksualitet og selvmord. Oslo: Scandinavian Academic Press.

Nybø, Reidun Kjelling (2007): Från tabu til tema. Selvmord i mediene. Kristiansand: IJforl.

Odén, Birgitta; Bodil E. B. Persson; Yvonne Maria Werner (1998): Den frivilliga döden. Samhällets hantering av självmord $i$ historiskt perspektiv. Stockholm: Cura i samarbete med Forskningsrådsnämnden.

Pleijel, Hilding (1983): Jordfästning $i$ stillhet. Från samhällsstraff till privatceremoni. Lund: Arken.

Suicidologi $2007 \mathrm{nr} 2$.

Westerlund, Michael (2010): Självmord och internet. Kommunikation om ett livsfarligt ämne. Stockholm: Institutionen för journalistik, medier och kommunikation.

$V G$ (2 December 2004): Berit (49) hengte seg på sykehusets röykerom (by Katrine Lia).

Ystads Allehanda (4 May 2007): Johanna Sällströms död (by Robert Jönson).

All the websites were accessed 1 March 2012 unless mentioned otherwise:

www.christiansellergren.se

www.eskilstuna.lny.se/

www.forum.kvinneguiden.no (accessed 1 April 2011)

www.freewebs.com/robbansminne/

www.journalisten.se

www.krokoline.vgb.no

www.levenorge.no

www.ludmilla.se

www.metrobloggen.se

www.minneavehline.blogg.se

www.ne.se/självmord

www.nollsuicid.blogg.se

www.pfu.no

www.po.se

www.presse.no

www.sjalvmord.com (accessed 1 April 2011)

www.spes.nu

www.tillminneav.se

www.ungaisorg.se 